\title{
EMPLOY SOME TRADITIONAL CRAFTS TOOLS IN THE EGYPTIAN FOLK DANCES AN INTRODUCTION
}

Samar Saeed SHABAN *

Academy of Arts, Higher Institute for Popular Arts, Egypt

\begin{abstract}
This research has demonstrated the importance of combining elements of popular culture and its spiritual aspects Social, mate rial, and everything that moves between members of society, whether it is obtained through individual effort, Or through the structured knowledge that is gained within formal institutions, and this research has focused To connect some elements of popular culture, such as crafts, tools, clothes, music and dance through Forms of cultural expression in which the spirit of human creativity is reflected, and the role of folk dances in Preserving the popular heritage.

Keywords

Traditional Crafts, Egypt, Folk, Dance.
\end{abstract}

\section{Introduction}

Folk arts represent the way of life in Egypt, with all its material and moral heritage. To understand the development, the arts that the peasant, worker and fisherman inherited from the Egyptian village, city, and coast, And folk arts are the historical and collective memory that reflects the originality of this people, and these arts combine elements Important to tell the inheritance of generations over the ages of ancestral culture.

Popular culture is all the spoken and other forms of expression that the memory stores Popularity, which is the collection of the elements that constitute the dominant culture of a society in any country or A limited geographical area, this culture results from the daily interactions between the elements of the society in addition to his needs and desires that constitute the daily life of the predominant sector of society, this culture includes all the social practices that the individual practices every day in his daily life.

Folk dance is one of the oldest types of dance, as it is closely linked to history, as it expresses the spirit Nationalism and the patriotic features of each society, and it is a living means of translating the feelings, beliefs and character of peoples.

It plays an important role in the recreation of the soul, and there is no civilized society or still living on instinct without entering Dancing in its celebrations and parties, for her, folk dancing stems from people because it is a social phenomenon that has its place since Foot so far.

Folk dance is considered the heritage of every people that reflects its customs, traditions and history across years and days. 
It is based on the step, movement and gesture, and it is performed by the common people, and it is a kinetic performance that stems from instinct. The youngster sees the celebrations held by the family, relatives, or clan, so he picks up the steps and movements and stores them in His mind to show these stocks at another time of his disappearance, and this type of dance did not interfere with science or technical techniques Modern in its method or in imposing scientific foundations, as it is a translation of the innate feelings with which man releases An expression of a feeling.

Given that folk dance and folk crafts tools are important forms that express practices Social, in which the most important characteristic of every Egyptian society is clearly visible. The folk is one of the important elements in the folklore as it sincerely expresses feelings and sentiments People and reflects the aspects of the social environment and hereditary traditions, "as the folklore is more A representation of the people's spirit, region, thinking, and standards in estimating matters.

Folk dance in general is characterized by its visual form and invisible content, in other words In terms of appearance and informer, as much as the appearance of the informant of the fun while watching as much as the informant of cultural depth highlights The relationship of the dance to the forms of popular culture. There is a growing, evident and present relationship between folk dance and other forms of popular culture.

This refers to the field work of the popular groups, so the researcher will deal with the dances Popularity in Egypt not only because it is a kinetic art, but also through linking it to the popular group that Created by its links to the customs and traditions of that group, and the role of tools used from environmental materials Which contributes significantly to all folk dances and how to employ them to express popular environments The different aspects of the Egyptian society, folk dance has an artistic and functional side, as it is artistic Kinetic creativity has grown, and my function in terms of the relationship of each dance separately to the function it performs in Community life.

The twentieth century witnessed a major shift in the course of research in folklore when they converged Inviting scholars and researchers to pay attention to the role of material culture, considering that it represents a vital pillar Whatever the cultural output of the popular group, many of these crafts and industries are struck With its roots in the depth of time for thousands of years, it moves over a wide ground, and it faces continuity Culturally, it includes countless values and beliefs that converge, interact, influence and are affected by knowledge and beliefs It is stored in the collective mentality in the Egyptian society, which is rich with elements and details that highlight each society Separately. 
The group is one of the most important elements of the folk tradition, as it performs an important function in crafting In determining its criteria for acceptance and adoption, and in its circulation, it also plays an important role in preserving But although the community is the primary axis of heritage, the creative individual is a point The main starting point with regard to the heritage elements, and all that the individual does in the community in terms of saying or constructing Homes, sewing, or making pottery are great legacies, but this is not done in isolation The group, the group is the main test in the emergence of heritage, and the group's approval of the individual's creativity is The correct approach to accepting it and moving it towards achieving the element of popularity.

\section{The importance of research}

Lies in identifying the elements that are used as auxiliaries from Tools of material culture in folk dances in order to highlight the most important elements characteristic of the nature of society In which this dance is presented with an explanation of the clothes and accessories that play a large role within Important elements in folk dances, and the researcher will review a group of dances that It characterizes the different Egyptian governorates and explains how to employ some elements of material culture within These dances.

Souad Othman - Studies in the folklore of Egyptian society - Girls' College - Ain Shams University If dance is a symbol of culture, then the generation of artists try to present high-end artistic performances. Intellectually and aesthetically expressing the community members using all forms that are consistent with their way of life.

Hence, it is characterized by movement and evolution, depending on the idea of movement, focusing on reformulation The popular heritage is within a dynamic art formation, and the artist, because of his artistic ability and a broad imagination, has many The freedom to transmit what he wants from the elements of popular creativity, so it is necessary for him to know The artist is concerned with the meaning, connotations, and function of the popular subjects from which he draws his inspiration.

Dancing and its other skills are playing with canes and swords, skills, tournaments and more That is, a fertile field for inspiration, but the artist designing the dance does not limit his creativity and innovation to Inspiration from folk dances with movements and formations only, but extends to other areas such as music Folklore, traditional crafts, traditional clothes and accessories, so he can take inspiration from them whatever he wants and the way he wants.

The creativity process, including its reception, reclassification, amendment, and the conception and creation that it contains All this is done in the conscience of the designer, and with the end 
we order with him to demand that he adhere to the popular character, Provided that the final influence of his work is within the scope of the last influence that the work suggests.

Popular in terms of taste and in terms of collective influence, and sometimes from the point of significance There are many folk crafts inherited from ancient times, and they bear many decorations like a craft Making dolls, pottery, mats, tents, carpets, and making five-finger knits from beads Blue, jewelry, furniture making, glass and metal, and this folk choreographer was used The elements that distinguish the letter and its use in folk dances. Each element is according to its use in the folk environment.

\section{References}

1- Ahmed Roshdy Saleh - Folklore Theater - Popular Arts Magazine - Egyptian Authority . General Book - Cairo - Issue 14

2- Suad Othman - Studies in the folklore of Egyptian society - Girls' College - Ain University. Shams 2013 p. 15

3- Ezz El Din Ismail, "The Employment of Heritage in the Theater" Fusoul Journal of the Egyptian Public Authority . For books Cairo 1980

4- Abdel Hamid Younis and others - Egyptian Folk Arts - State Information Service . Alexandria House for Printing and Publishing - 1994

5- Farouk Ahmed Mustafa - Al-Samer Songs - Popular Arts Magazine, Commission Press . The Egyptian General Book, No. 42

6- Nafisa al-Ghamr Rawi - Defining Folk Dance - "On the Origins of Folk and Pharaonic Dancing”. The publisher Mohammed Al-Amin General

Received: February 3, 2018

Accepted: April 30, 2018 